\title{
Accounting
}

\section{Determinants influencing audit delay: The case of Vietnam}

\section{Thi Thu Thuy Lai ${ }^{a^{*}}$, Manh Dung Tran ${ }^{b}$, Van Tuong Hoang ${ }^{c}$ and Thi Hong Lam Nguyen}

\author{
${ }^{a}$ Thuongmai University, Vietnam \\ ${ }^{b}$ National Economics University, Vietnam \\ ${ }^{c}$ Academy of Finance, Vietnam
}

\begin{tabular}{l}
\hline C H R O N I C L E \\
\hline Article history: \\
Received March 92020 \\
Received in revised format March \\
152020 \\
Accepted May 182020 \\
Available online \\
May 182020 \\
\hline Keywords: \\
Audit delay \\
Financial reporting \\
FDI firms \\
Vietnam
\end{tabular}

This research is conducted to investigate determinants that affect delays in the signing of audit reports in Vietnam. The audit delay is measured as a function of the number of days that elapse from the accounting period until the date when the audit report is signed. This study employs a sample of 142 foreign direct investment (FDI) firms in Vietnam in 2019. We use Linear regression analysis, modelling audit delay as a function of the following explanatory variables: firm size, audit firm type, sign of income, audit opinion, and leverage. The findings indicate that the firms that report net income, that have standard audit opinion, and that have bigger size release their audited financial statements earlier. Variables such as auditor firm and leverage show no significant relationship with audit delay.

\section{Introduction}

The objective of financial statements is to provide information about the entity that is useful to a wide range of users in decision making. In order to be useful for decision making, financial statements should be understandable, relevant, reliable, and comparable. Many accountants, managers and financial analysts believe that timeliness is an important characteristic of financial statement since timely reporting provides more decision-useful information. Timeliness is an old and important concept in accounting and stresses the importance of making information available to decision makers while it can still be used (McNabb, 2010). Timeliness of financial reporting is crucial to all users of financial reports. This is due to the fact that many users specifically the shareholders and potential investors depend on what they see on the audited financial statement prior the time of making any investment decision. An increase on the reliability of the reports may go up once the statements are carefully audited by some external auditor. In Exposure Draft of an Improved Conceptual Framework for Financial Reporting (2008) issued by International Accounting Standard Board, that reliability as an important qualitative characteristic of decision-useful financial reporting information is stated. Users may feel confident on the reports certified by the auditors and may be able to make wise decisions (FASB, Concepts Statement 2).

Vietnamese foreign direct investment (FDI) firms are frequently unable to provide the audited financial statement timely for the users. The reporting delay from the company's accounting year end to the date of the audit report completed is a situation of audit delay or audit report lag (Ashton et al., 1987). Audit report lag would lead the shareholders and potential shareholders to

* Corresponding author.

E-mail address: laithuy@tmu.edu.vn (T.T.T. Lai) 
postpone their transaction on shares ( $\mathrm{Ng} \&$ Tai, 1994). This in turn, would provide negative effect to the company. OwusuAnsah (2000) provides that audit timeliness is the one factor that will influence on the timeliness of financial statements.

The audit report date is the date on which the auditor has obtained sufficient appropriate audit evidence to support the opinion, including evidence that all financial statements have been prepared and that the management has asserted that they have taken responsibility for those financial statements. Therefore, a better understanding of factors affecting audit delay will immensely enhance the efficiency of audit work leading to informed decisions. Further, the availability of reliable and timely financial information for decision making reduces the information asymmetry prevailing between corporate entities and their stakeholders in emerging markets.

The objective of this paper is to review the literature on audit delay and the determinants that affect delays in the signing of audit reports in Vietnam. The first section provides the review of previous studies on audit delay and factors affecting audit delay. Next, it provides the discussion on the effect of company size, audit firm type, sign of income, audit opinion, and leverage on audit delay in Vietnam, and the last section is on conclusion part which includes future research avenues.

\section{Literature review}

\subsection{Audit delay}

Audit delay is computed based on the time spent or the number of calendar days between the fiscal year-end and the audit report date. Timeliness needs that information ought to be made available to financial statement users as quickly as possible and it is an essential condition to be satisfied as long as the financial statements are found useful. Under different circumstances, audit delay has been investigated according to timeliness (Hossain \& Taylor, 1998). A number of studies have examined the determinants of audit report lag. Some were conducted in developed countries such as in the UK, U.S, Australia, Canada and New Zealand and some other studies were conducted in the developing countries such as in Bangladesh, Hong Kong, China, Egypt, Russia, Pakistan, India and Malaysia.

Stamp (1966) conducted the first empirical study of the effect of audit delay on the timeliness of annual accounts. He investigated what he called the question of speeding accounts which affected New Zealand shareholders with a comparative study to compare the timeliness of four New Zealand and four Australian firms, on the one hand, with four US firms on the other. In spite of the US firms being larger on average than both the New Zealand and Australian firms, Stamp found that the auditors in Australia and New Zealand took approximately twice as long to report as the American auditors. The American auditors' reports were made available approximately 40 days after their clients' balance dates, while the Australian and New Zealand auditors took approximately 80 days (Hossain \& Taylor, 1998).

Owusu-Ansah (2000) provided some results that auditors in Zimbabwe, on average, spent 62 days from a company's fiscal yearend to the date of the audit reports' signature, while companies spent from 7 to 23 days after the auditors had certified the accounts to release their annual reports. Hossain and Taylor (1998) empirically investigated the effect of selected corporate attributes on audit delay for a selected of 103 nonfinancial companies listed on the Karachi Stock Exchange (KSE) for the year 1993. They reported that audit delay was usually reported by the Pakistani listed firms took around 143 days, 100 and 60 days longer than audit delay in the US and Australia, respectively.

Two major studies reporting an increase in audit delay were conducted in New Zealand and Australia. Carslaw and Kaplan (1991) examined audit delay for a large sample of New Zealand public firms from 1987 to 1988. Descriptive statistics for the sample firms for the two years indicated that the mean audit delay for 1987 and 1988 was approximately 88 and 95 days, respectively, which was longer than that reported by previous studies. The authors attributed the increase in audit delay to the rapid growth in the size and number of firms listed on the New Zealand Stock Exchange which had not kept pace with the times. It was also argued that the firms' operating and financing environment had also become more sophisticated and complicated, leading to more complex auditing and accounting procedures. Simnett et al. (1995) studied the timeliness of corporate audit reporting by using nine years of data (1981-1989) collected on Australian firms listed on the Australian Securities Exchange (ASX). The results indicated that audit delay had increased gradually over the nine years to approximately 88 days as a consequence of the fact that the business environment that firms operate in had become more complex and uncertain. On the contrary, a 15-year survey of audit delay by Givoly and Palmon (1982) indicated that the mean delay had decreased from 61 days in 1960 to just 41 days in 1974. The writers argued that the improvement in timeliness should be contributed due to several items. An increase in advanced data processing devices and the development of internal control systems could lead to a quicker preparation of financial statements which yields to less audit period. As companies shifted to a system of quarterly reports, there was a bigger involvement of auditors throughout the year. Auditors learnt more about business operations which also indicated that they were capable of conducting faster annual audits.

All the empirical studies explained indicate the existence of audit delay in financial reporting all around the world. Some of these longitudinal studies demonstrate the patterns of audit delay over the years and even give a rationale for the change in audit 
delay. In order to learn about the source of audit delay, nevertheless, a review on prior studies may determine more factors of audit delay. Thus, the next section provides a discussion of empirical research conducted on factors affecting audit delay to determine the factors that can be applied to study audit delay in Vietnam.

\subsection{Determinants influencing audit delay}

It is important to understand factors that influence audit delay since it directly affects the timeliness of financial reporting. Still, there are numerous studies that have examined a variety of factors regarding audit delay. These factors include, among others, size of the company, audit firm size, type of audit opinion, profitability, debt to leverage.

\section{Auditee's size}

The size of company measured by total assets is the most popular factor of audit delay that has been employed in previous studies (Ashton et al., 1989b; Courtis, 1976; Davies \& Whittred, 1980; Gilling, 1977; Newton \& Ashton, 1989; Carslaw \& Kaplan, 1991; Abdulla, 1996). Most of these prior studies found a negative association between the audit delay and the firm size. This is possibly due to the ability of larger firms to pressure auditors to complete the audit work in a timely manner (Ahmad \& Kamarudin, 2003). In addition, larger firms may have their audit reports completed earlier than smaller ones because larger firms may have stronger internal controls, which affect the audit work due to the tendency for the auditor being expected to rely more on internal controls and reduce the extent of substantive tests (Almosa \& Alabbas, 2007).

Considered to be the first study on audit delay in Australia, Dyer and McHugh (1975) examined the relationship between selected corporate attributes and reporting delay using univariate analysis. The study found that company size was related to audit delay as larger firms (with assets over $\$ 5$ million) had consistently been more timely reporters than smaller firms. This was to be expected as large firms were more in the public eye and depended on maintaining a reputation of timeliness to attract investors.

Gilling (1977) found company size to be a significant determinant of audit delay specifically as a result of the manner in which auditing firms in New Zealand scheduled their work. The leading auditing firms scheduled their work in the following order: overseas firms, large public firms and smaller public firms. In spite of the more complex accounting work involved in large firms, it was found that firms with total assets over NZ\$50m and overseas firms operating in New Zealand had shorter audit report lags. Gilling explained that this ordering of priorities was partly a result of client pressure on auditing firms but, more significantly, it was caused by the auditor's need to plan, control and even out the work flow. He also argued that since large firms consumed more of the auditor's time and costs than smaller firms, auditors sped up the completion of large firms' audits to obtain a speedier recovery of fees.

In their study on audit delay in Zimbabwe, Owusu-Ansah (2000) found some significant results for company size from a twostage regression which indicated that larger firms in Zimbabwe were more likely to release their annual reports faster than smaller firms. The authors explain that large firms in Zimbabwe may have the resources to employ modern technology which enables them to release their annual reports on a timely basis

\section{Auditor's size (Auditors)}

Another explanatory variable is the size of audit firm. Several studies have examined empirically the association between the attribute of the audit firm (size of audit firm or international link of the auditing firm) and audit report lag. Most of the prior researches about this subject investigates whether audited by Big audit firms have any positive effect on the audit lag. It is expected that the audit lag for the Big 4 firms will be lesser than the audit lag for the smaller firms. This is because the Big 4 firms are large firms and thus it is assumed that they are able to audit more efficiently and have greater flexibility in scheduling the audits so that it can be completed on time. However, a negative effect can also be expected since the numbers of Big four clients are much more than small auditing firms. In other words, it can be expected that firms that are audited by big four publish their financial statements later than other firms that are audited by small audit firms.

Gilling (1977) is credited with one of the first studies to examine the relationship between corporate reporting lag and the attributes of auditors. Gilling studied a sample of 187 New Zealand public firms that represented 73 per cent of all listed public firms in New Zealand, with data being collected from a survey of the 1976 annual reports. The study showed that the number of accounting firms providing audit services to public firms in New Zealand was highly concentrated with the seven largest firms auditing over 80 per cent of all New Zealand public firms. It was reported that, on an average, the seven largest auditing firms were able to perform the audit and sign their reports in a shorter time than other auditors. While the leading seven firms produced their audit reports in only 75 days, the remaining auditing firms took nearer 90 days, on average, to perform the audit. This study established the relevance of audit size to the timeliness of financial reporting and audit delay.

In order to provide an adequate explanation for corporate reporting lags, Davies and Whittred (1980) extended on Dyer and McHugh's (1975) study by pursuing Gilling's (1977) suggestion that auditing firms attributes should be examined to explain reporting delay. A replication of Dyer and McHugh's study was conducted by Davies and Whittred (1980) using a sample of 
100 commercial and industrial Australian firms listed on the Australian Securities Exchange (ASX) over the period 1972 to 1977. It was found that auditing firm size was a major determinant of reporting delay in Australia. The results showed that firms audited by the larger auditing firms (the Big 8) had shorter delays than those that were audited by other auditing firms. To explain this result, the Davies and Whittred (1980) argued that larger Big 8 auditing firms most often have larger clients which are more likely to have 'on-going' audits than small firms. Also, the Big 8 firms are more efficient because they have better resources and the ability to access modern technology.

Modugu et al. (2012) examined the relationship between audit firm size and audit delay in a new contest, Nigeria, by using a sample of 20 firms was selected for a period of 2009 to 2011 . The results showed that the audit delay was ranged from a minimum delay of 30 days to a maximum delay of 276 days while the average of the delay was approximately two months. In addition, the results indicated also that audit firm size was found not significantly associated with audit delay.

\section{Type of audit opinion}

Several authors (Whittred, 1980; Carslaw \& Kaplan, 1991; Ashton et al., 1987; Newton \& Ashton, 1989; Leventis et al., 2005; Bonsón-Ponte et al., 2008) have introduced qualifications or reservations expressed by the auditor as one of the factors that may determine the delays observed in auditing. The qualified opinion is viewed as representing a negative view of the firms ${ }^{\text {ee }}$ financial affairs and thus slows down the audit process (Che-Ahmad \& Abidin, 2009). Bamber et al. (1993) argued that a qualified opinion is not likely to be issued until the auditor has spent considerable time and effort in performing additional audit procedures. Moreover, Leventis et al. (2005) have argued that "auditors are expected to extend tests when they find or suspect irregularities, and partly because auditors might wish to take more time to audit transactions as a defense against any potential future litigation". Ashton et al. (1987) used an auditor-specific sample of firms contrary to previous studies which relied on secondary data sources to examine the determinants of audit delay, in order to formulate a systematic relation between audit delay and audit-related variables. These were relative mix of audit work performed at interim and final dates, number of years of audit experience (of the auditing firm with the company) and type of audit opinion. It was found that audit lag was significantly shorter for firms that (1) receive unqualified audit opinions, (2) had a less relative amount of audit work performed after yearend.

\section{Profitability}

Several researchers have used profitability as an explanatory variable for audit delay (Ashton et al., 1987, Carslaw \& Kaplan, 1991, Bamber et al., 1993). They argued that firms reporting a profit for the period are expected to minimize audit delay compared to the ones reporting a loss. Therefore, a negative association is expected between the audit delay and firms reporting a profit. The argument behind this is that firms with a profit are expected to attempt to invite the auditor to complete the audit engagement as quickly as possible to release their audited financial reports (Hossain and Taylor, 1998). Focusing specifically on profitability, Givoly and Palmon (1982) investigated the relationship between the timeliness of annual reports, their contents and certain company attributes using a sample of 210 firms in 25 different industries listed on the New York Stock Exchange. Givoly and Palmon (1982) showed that there was a consistent order in the earnings release dates of firms in 21 of the 25 selected industries depending on profitability. Results indicated that bad news tended to be delayed due to "the managers' natural desire to defer any repercussions from shareholders and managers' wish to continue and complete recent negotiations and contracts in the best possible light".

\section{Debt to leverage}

Financial leverage is the use of certain sources of funds that will result in fixed costs in the form of interest costs. The source of these funds can be in the form of debt bonds, credit and banks and so on. Financial leverage arises if a company uses long-term debt with fixed interest to finance its investment, because of this fixed nature, the company continues to bear interest regardless of whether the company makes a profit or not. When company profits are small, fixed interest costs will reduce yields to shareholders. Instead interest costs are fees that can be taxed. Therefore, firms receive subsidies on interest expenses. Under these conditions, the interest subsidy will increase returns to shareholders (profit after tax). Thus, financial leverage measures the level of return sensitivity for each share (EPS) due to changes in income before interest and taxes (EBIT). According to Mckinnie (2016), leverage ratio is the company's ability to meet its liability. If the company has a high leverage ratio, the risk of loss will increase. Therefore, to gain confidence in the company's financial statements, the auditor will increase his prudence so that the audit report lag span will be longer.

Besides, it has been argued that increasing the amount of debt a firm uses, will put pressure on the firm to provide its creditors with audited financial reports more quickly (Abdulla, 1996).

\section{Research methodology}

The aim of this research is to investigate the effects of firm size, sign of income, leverage, audit opinion, and auditor firm on audit delay for FDI firms in Vietnam. Based on Hair et al. (2006), the sample size is at least 100. We chose our sample consists 
of 142 FDI firms that are convenient to collect data. The data for each of the 142 sample firms were taken from their annual reports.

To better understand how FDI firms respond to the timely reporting requirements, it is necessary to relate their timely reporting practices to certain factors. This study investigates some of these factors that are relevant to the socio-economic conditions in Vietnam and for which data were available. The factors include the company size (SIZE), the audit firm (AUDITOR), audit opinion (OPINION), sign of income (INCOME), and debt to equity ratio (LEVERAGE). Therefore, the hypotheses of this study are drawn below:

$\mathrm{H}_{1}$ : Audit delay is a function of a firm size.

$\mathrm{H}_{2}$ : Audit delay is a function of an auditor.

$\mathrm{H}_{3}$ : Audit delay is a function of sign of income.

$\mathrm{H}_{4}$ : Audit delay is a function of audit opinion.

$\mathrm{H}_{5}$ : Audit delay is a function of debt to leverage.

As in prior studies, we define "audit lag" as the number of days between a company's financial year-end and the day of the audit report. If a firm releases its financial statements within regulatory deadline, then, it cannot be said that the company has delayed in releasing its financial statements. Therefore, we describe the number of days that elapses between a company's financial yearend and the date of audit report as its audit lag. We computed the audit delay for each company by counting the number of days that elapsed between its financial year-end and the date of the audit report. To investigate the influence of the selected factors on audit lag in our sample, we estimated the following cross-sectional regression model. Table 1 shows the explanation of the explanatory independent variables.

$A U D I T L A G=b_{0}+b_{1} \times S I Z E+b_{2} \times A U D I T O R+b_{3} \times I N C O M E+b_{4} \times O P I N I O N+b_{5} \times L E V E R A G E+e$

Table 1

Definitions of independent variables

\begin{tabular}{|c|c|}
\hline $\begin{array}{l}\text { Independent } \\
\text { Variables }\end{array}$ & Explanations \\
\hline SIZE & Total assets of an entity \\
\hline AUDITOR & Type of audit firm represented by a dummy variable: "Big 4 audit firms" assigned a 0 , otherwise 1. \\
\hline INCOME & $\begin{array}{l}\text { Sign of current year income represented by a dummy variable: firms with "positive net income" } \\
\text { assigned a } 0 \text {, otherwise } 1 .\end{array}$ \\
\hline OPINION & Type of audit opinion represented by a dummy variable: "standard opinion" assigned a 0 , otherwise 1. \\
\hline LEVERAGE & Total debt / Equity \\
\hline
\end{tabular}

\section{Results and discussion}

Table 2 presents summary statistics of the variables used in this study. As is evident, it takes FDI firms approximately 63 days, on average, to report to the public after the end of their financial year. The standard deviation for the AUDITLAG variable is 13 days, suggesting considerable variability in timely reporting by the firms. It is found that $50.7 \%$ of the sample was audited by big four audit firms and $76.01 \%$ of the firms audit report was standard. $66.2 \%$ of the firms report net income for the year 2017.

Table 2

Summary statistics

\begin{tabular}{lccc}
\multicolumn{1}{c}{ Variables } & Mean & Standard Deviation & Percentage (*) \\
\hline AUDITLAG & 62.62 & 4.305 & \\
SIZE & 193.82 & 142.690 & 50.7 \\
AUDITOR & & & 66.2 \\
INCOME & & & 76.1 \\
OPINION & & & \\
LEVERAGE & 34.3449 & 13.67493 & \\
\hline
\end{tabular}

(*) \% of firms whose dummy variable was coded as 0

Table 3 shows the results from comparison of means between the dichotomous variables. From the table, it can be seen that on average, the audit delay increases with the presence of a loss, qualified audit opinion and by small audit firms. As for AUDITOR, the mean delay for small audit firms is higher by about 1 day than those for big 4 audit firms with a mean delay of only 62 days. 
Regarding INCOME, firms suffering from losses seem to have a longer mean delay than those gaining a positive net income. Firms receiving a qualified audit opinion also seem to take on average of 5 days more than those receiving a clean audit report.

Table 3

Mean differences for dichotomous variables

\begin{tabular}{lcc}
\hline AUDITLAG & \multicolumn{2}{c}{ Independent Variables } \\
\hline AUDITLAG & Big 4 Audit Firms & Non-Big 4 Audit Firms \\
Mean & 62 & 63 \\
Standard Deviation & 4.302 & 4.334 \\
AUDITLAG & Standard Opinion & Others \\
Mean & 62 & 67 \\
Standard Deviation & 3.789 & 3.586 \\
AUDITLAG & Net Income & Loss \\
Mean & 61 & 66 \\
Standard Deviation & 3.776 & 3.324 \\
\hline
\end{tabular}

Table 4, 5, 6 present the multiple regression results for the sample.

\section{Table 4}

The summary of the statistics associated with the regression estimate

\begin{tabular}{lccccc}
\hline Model & $\mathrm{R}$ & R Square & Adjusted R Square & $\begin{array}{c}\text { Std. Error of the } \\
\text { Estimate }\end{array}$ & Durbin-Watson \\
\hline 1 & $.729^{\mathrm{a}}$ & .531 & .514 & 3.001 & 1.198 \\
\hline
\end{tabular}

a. Predictors: (Constant), SIZE, LEVARAGE, AUDITOR, INCOME, OPINION

b. Dependent Variable: AUDITLAG

\section{Table 5}

The results of ANOVA test

\begin{tabular}{llccccc}
\hline Model & & Sum of Squares & df & Mean Square & F & Sig. \\
\hline \multirow{2}{*}{1} & Regression & 1388.431 & 5 & 277.686 & 30.828 & $.000^{\mathrm{b}}$ \\
& Residual & 1225.034 & 136 & 9.008 & & \\
\cline { 2 - 7 } & Total & 2613.465 & 141 & & & \\
\hline
\end{tabular}

a. Dependent Variable: AUDITLAG

b. Predictors: (Constant), SIZE, LEVARAGE, AUDITOR, INCOME, OPINION

\section{Table 6}

The results of regression estimate

\begin{tabular}{|c|c|c|c|c|c|c|}
\hline \multirow{2}{*}{\multicolumn{2}{|c|}{ Model }} & \multicolumn{2}{|c|}{ Unstandardized Coefficients } & \multirow{2}{*}{$\frac{\text { Standardized Coefficients }}{\text { Beta }}$} & \multirow[t]{2}{*}{$\mathrm{t}$} & \multirow[t]{2}{*}{ Sig. } \\
\hline & & $\mathrm{B}$ & Std. Error & & & \\
\hline \multirow{6}{*}{1} & (Constant) & 63.069 & .894 & & 70.531 & .000 \\
\hline & AUDITOR & .230 & .508 & .027 & .452 & .652 \\
\hline & INCOME & 2.845 & .591 & .314 & 4.815 & .000 \\
\hline & OPINION & 2.578 & .655 & .256 & 3.933 & .000 \\
\hline & LEVARAGE & .003 & .019 & .009 & .153 & .879 \\
\hline & SIZE & -.012 & .002 & -.383 & -5.682 & .000 \\
\hline
\end{tabular}

a. Dependent Variable: AUDITLAG

From the above results, it can be seen that:

Multi-collinearity testing: The VIF of all independent variables is less than 10 , so the multi-collinearity in the model is considered not to be serious.

The Durbin Watson Test is a measure of autocorrelation (also called serial correlation) in residuals from regression analysis. The Durbin-Watson value is 1.198 (between 1 and 3). Model does not have autocorrelation.

Result of ANOVA test with Sig. $=0.000$ shows that the linear regression model was constructed in accordance with the dataset and was usable. 
The $\mathrm{R}^{2}(\mathrm{R}$ Square $)=0.531$ indicates that $53.1 \%$ of the variation in AUDITLAG of financial statements of FDI firms in Vietnam will be explained by factors with independent variables in the research model.

The coefficient estimates for SIZE, INCOME, OPINION are all statistically significant (Sig. $<5 \%$ ). Audit delay was positively associated with OPINION, INCOME and negatively associated with SIZE. This means that audit lag decreases with the presence of income and standard audit report. Thus, the research hypotheses H1, H3, H4 are accepted. On the other hand, the AUDITOR coefficient and LEVERAGE coefficient are statistically not significant (Sig. >5\%). Therefore, the research hypotheses H2, H5 are rejected.

It was also found that firms receiving a qualified audit opinion seem to suffer from a longer audit lag than those receiving a standard (clean) audit report. Logically, it can be argued that auditors need to spend considerable amount of time and effort in pursuing audit procedures to confirm the qualification or maybe possibly to avoid such qualification. The other finding of this study is that firms that report net income for the period publish their financial statement 5 days earlier than other firms that report loss for the period.

In addition, it is found that firms that have standard audit reports publish their financial statements 5 days earlier than other firms that have qualified or adverse opinions.

In short, this paper has investigated the effects of factors such as company size, sign of income, leverage, audit opinion, and auditor firm on timely financial reporting practices in a developing country, Vietnam. For this objective, financial statements and audit reports of 142 FDI firms were analyzed. According to empirical results; $53.1 \%$ of the variation in the audit lag in our model is explained by variations in company size, auditor firm, sign of income, audit opinion, and leverage. The coefficient estimates for INCOME, OPINION and SIZE are all found statistically significant. Besides, the coefficient estimates for LEVERAGE and AUDITOR coefficient are found statistically not significant.

Timeliness is an important and useful characteristic of accounting information. Thereby, it is of great interest to different regulatory bodies and standard setters. However the timeliness of financial reporting is directly affected by the length of auditing. Our data indicate that the average audit delay in Vietnam FDI firms is 63 days. The aim of this study was to analyse the effect of several FDI company and audit related variables on audit delay in Vietnam. Our findings indicate that audit lag decreases with the presence of income and standard audit report, while audit lag increases in the smaller firms. The results of this paper could be of interest not only to academics but also to standard setters and regulators in the process of improvement of the quality of financial reporting. However, potential limitations of our study are related to a small sample size, sample selection bias and the problem of omitted variables (namely variables that explain different corporate governance aspects, institutional setting, audit firm and audit technology characteristics). These limitations can also be used as suggestions for future research.

\section{References}

Abdulla, J.Y.A. (1996). The Timeliness of Bahraini Annual Reports. Advances in International Accounting, 9, 73-88.

Ahmad, R.A.R., Kamarudin, K.A. (2003). Audit delay and the timeliness of corporate reporting: Malaysian evidence. Communication Hawaii International Conference on Business, June, University of Hawaii-West Oahu.

Almosa, S. \& Alabbas, M. (2007). Audit delay: Evidence from listed joint stock companies in Saudi Arabia. King Khalid University, Saudi Arabia.

Ashton, R.H., Graul, P.R., \& Newton, J.D. (1989). Audit delay and the timeliness of corporate reporting. Contemporary Accounting Research, 5(2), 657-673.

Ashton, R.H., Willingham, J.J., \& Elliott, R.K. (1987). An empirical analysis of audit delay. Journal of Accounting Research, 25(2), 275-292.

Bamber, E.M., Bamber, L.S., \& Schoderbek, M.P. (1993). Audit structure and other determinants of audit report lag: An empirical analysis. Auditing: A Journal of Practice \& Theory, 12(1), 1-23.

Bonson-Ponte E., Escobar-Rodriguez, T., \& Borrero Dominguez, C. (2008). Empirical analysis of delays in the signing of audit reports in Spain. International Journal of Auditing, 12, 129-140.

Carslaw, C., \& Kaplan, S.E. (1991). An examination of audit delay: Further evidence from New Zealand. Accounting and Business Research, 22(85), 21-32.

Che-ahmad, A. \& Abidin, S. (2009). Audit delay of listed companies: A case of Malaysia. International Business Research, 1, 32-39.

Courtis, J.K. (1976). Relationships between timeliness in corporate reporting and corporate attributes. Accounting and Business Research, 7(25), 45-56.

Davies, B., \& Whittred, G.P. (1980). The association between selected corporate attributes and timeliness in corporate reporting: further analysis. Abacus, 16(1), 48-60.

Dyer, Jc. \& McHugh, A. (1975). The timeless of the Australian annual report. Journal of Accounting Research, 13(2), 204-219. Financial Accounting Standards Board (2008). Original pronouncements as amended, Statement of Financial Accounting 
Concepts No. 2 Qualitative Characteristics of Accounting Information.

Gilling, D.M. (1977). Timeliness in corporate reporting: Some further comment. Accounting and Business Research, 8, 35-50.

Givoly, D., \& Palmon, D. (1982). Timeliness of annual earnings announcements: Some empirical evidence. Accounting Review, 57(3), 486-508.

Hair, J.F., Black, W.C., Babin, B.J., \& Anderson, R.E. (2006). Multivariate Data Analysis. New Jersey: Pearson International Edition.

Hossain, M. \& Taylor, P. (1998). An examination of audit delay: Evidence from Pakistan. Working Paper, University of Manchester.

IASB (2008). Exposure Draft of An Improved Conceptual Framework for Financial Reporting: Chapter 1: The Objectives of Financial Reporting, Chapter 2: Qualitative Characteristics and Constraints of Decision-useful Financial Reporting Information.

Leventis, S., Weetman, P. \& Caramanis, C. (2005). Determinants of audit report lag: Some evidence from the Athens Stock Exchange. International Journal of Auditing, 9, 45-58.

Mckinnie, M. (2016). Cloud computing: TOE adoption factors by service model in manufacturing. Dissertation, Georgia State Unversity, USA.

McNabb, D.E. (2010). Research Methods for Political Science: Quantitative and Qualitative Approaches, ME Sharpe Inc.

Modugu, P.K, Eragbhe, E \& Ikhatua, O.J. (2012). Determinants of audit delay in Nigerian companies: Empirical evidence. Research Journal of Finance and Accounting, 3(6), 46-54.

Ng, P. P., \& Tai, B. Y. (1994). An empirical examination of the determinants of audit delay in Hong Kong. The British Accounting Review, 26(1), 43-59.

Newton, J. D., \& Ashton, R. H. (1989). The association between audit technology and audit delay. Auditing-a Journal of Practice \& Theory, 8, 22-37.

Owusu-Ansah, S. (2000). Timeliness of corporate financial reporting in emerging capital markets: empirical evidence from the Zimbabwe Stock Exchange. Accounting \& Business Research, 30, 241-254.

Owusu-Ansah, S. and Leventis, S. (2006). Timeliness of Corporate Annual Financial Reporting in Greece: A Research Note. European Accounting Review, 15(2), 273-287.

Simnett, R., Aitken, M, Choo, F. \& Firth, M. (1995). The determinants of audit delay. Advances in Accounting, $13,1-20$.

Soltani, B. (2002). Timeliness of corporate and audit reports: Some empirical evidence in the French context. The International Journal of Accounting, 37, 215-246.

Stamp, E. (1982). First steps towards a British conceptual framework. Accountancy, March, 123-130.

Whittred, G.P. (1980). The timeliness of the Australian Annual Report: 1972-1977. Journal of Accounting Research, 18, 623628.

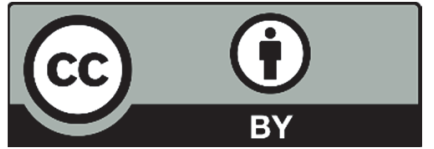

(C) 2020 by the authors; licensee Growing Science, Canada. This is an open access article distributed under the terms and conditions of the Creative Commons Attribution (CC-BY) license (http://creativecommons.org/licenses/by/4.0/). 